\title{
ISU-ISU SOSIAL MASYARAKAT DALAM TAFSIR \\ (Kajian Analisis Wacana Tafsir Täj al-Muslimīn min Kalāmi Rābb al-‘Alami \\ karya K.H. Misbach Mustafa)
}

Syihabuddin Alwy

Email: Alawysyihab@gmail.com

Nawal Nur Arofah

STAI Al Anwar

Gondanrojo Kalipang Sarang

Email: nok_awang@yahoo.co.id

\begin{abstract}
Abstrak
Sifat al-Qur`an yang Șālihun likuli zamān wa al mākān menjadikannya sebagai kitab suci yang sangat terbuka untuk ditafsirkan (multi interpretable). Kondisi sosial-kultural dan situasi politik juga menjadi hal yang mempengaruhi penafsir. Disamping itu dalam dinamika perkembangan tafsir ada kecenderungan dalam diri seorang muffasir untuk memahami al-Qur`an sesuai sudut pandang ilmu yang ditekuninya. Berangkat dari hal tersebut maka al-Qur'an harus dijadikan sebagai landasan moral-teologis dalam rangka menjawab problem-problem sosial-keagamaan dan sosial-kemasyarakatan di era modern-kontemporer. salah satunya adalah kitab tafsir Tāj al-Muslimīn karya K.H. Misbach Mustafa. Dalam kitab tafsir tersebut K.H. Misbach Mustafa memasukan beberapa isu-isu sosial yang terjadi di masyarakat. Diantaranya riba bunga bank, program Kelurga Berencana, pengunaan pengeras suara, dan basmallah dalam surat alFatihah. Masuknya isu-isu sosial tersebut merupakan bentuk dari kehati-hatian beliau dalam urusan agama dan akidah. Apalagi hal tersebut merupakan hal yang bersentuhan langsung dengan kehidupan masyarakat. Posisi beliau sebagai orang yang terpelajar dan memahami ajaran-ajaran agama membuatnya tergugah untuk menjaga umat yang awam dari apa yang dianggapnya sebagai kekeliruan dan kesesatan. Sebab, terkadang isu-isu sosial tersebut bersebrangan atau malah bertentangan dengan ajaran atau ketentuan agama Islam. Masuknya isu-isu sosial masyarakat dalam tafsir itu sendiri disebabkan karena adanya kesinambungan antara tema pokok ayat al-Qur'an dengan isu-isu sosial yang terjadi di masyarakat.
\end{abstract}

Key Words : Tāj Muslimin, Isu Sosial, K.H. Misbach Mustafa

\section{A. Pendahuluan}

Kajian Terhadap al-Qur`an dari berbagai segi, terutama dari segi penafsiran selalu menunjukan perkembangan signifikan, sejak diturunkannya al-Qur'an hingga sekarang ini. Munculnya berbagai penafsiran terhadapnya dan banyakanya karya tafsir yang sarat dengan berbagai ragam dan metode pendekatan, merupakan bukti bahwa upaya untuk menafsirkan al- 
Qur'an tidak pernah berhenti. ${ }^{1}$

Pembacaan terhadap al-Qur`an, baik dari segi pola penafsiran, epistimologi, metodologi, dan lain sebagainya telah berkembang dari masa ke masa. Bahkan tidak pernah berhenti selama proses penafsiran dilakukan. ${ }^{2}$ Karena al-Qur'an sendiri memang sangat terbuka untuk ditafsirkan (multi-interpretable), dan sangat mungkin masing-masing mufasir ketika menafsirkan al-Qur’an juga dipengaruhi oleh kondisi sosio-kultural dimana ia tinggal, bahkan situasi politik yang melingkupinya juga memiliki andil dalam penafsiranya. Di samping itu, dalam dinamika perkembangan tafsir, ada kecenderungan dalam diri seorang muffasir untuk memahami al-Qur`an sesuai sudut pandang ilmu yang di tekuni, sehingga meskipun obyek kajiannya tunggal (yaitu: teks al-Qur'an), namun hasil penafsirannya tidaklah tunggal. ${ }^{3}$

Fenomena tersebut merupakan konsekuensi logis dari adanya keinginan umat Islam untuk selalu mendialogkan antara al-Qur'an dan teks (nash) yang terbatas, dengan perkembangan problem sosial kemanusiaan yang dihadapi sebagai konteks (waqa'i) yang tidak terbatas. Hal ini juga merupakan salah satu implikasi dari pandangan teologis umat Islam bahwa al-Qur’an itu șālihun likulli zamān wa al mākān. ${ }^{4}$

Di Indonesia menurut Gusmian, dalam Khazanah Tafsir Nusantara: Dari Hermeunetika sampai Ideologi bahwa pada tahun 1970-an sampai pada 1990-an tafsir di Indonesia terus mengalami perkembangan termasuk di dalamnya tafsir karya K.H. Misbach Mustofa. Dalam karyanya tersebut beliau melahirkan suatu hal yang tidak hanya baru, akan tetapi juga mengesankan: bahwa kontruksi nalar tafsir (ternyata) mempunyai kaitan erat dengan episteme dan nalar yang ada dalam diri penafsir. Dari arah ini, Gusmian dengan tajam memperhatikan: ada karya tafsir yang membangun visi perlawanan terhadap rezim orba, yang berselingkuh dan mendukungnya, membangun sensitivitas gender, dan yang sebaliknya, serta yang terjebak dalam komunalisme agama. ${ }^{5}$

\footnotetext{
${ }^{1}$ Abdul Mustaqim, Madzhibut Tafsir : Peta Metodelogi Penafsiran al Qur an Priode Klasik hingga kontemporer (Yogyakarta: Nun Pustaka: 2003), v.

2 Abdul Halim, “Epistimologi Tafsir Ibnu 'Āsyūr dalam Kitab Tafsir al Tah̆n̄̄r wa Tanwīr”. Skripsi. Fakultas Ushuluddin UIN Sunan Kalijaga.Yogyakarta, 2011. 2.

${ }^{3}$ Abdul Mustaqim, Dinamika Sejarah Tafsir al Qur 'an, (Yogyakarta: Adab Press, 2014), 6-7.

${ }^{4}$ Abdul Mustaqim, dkk, Studi al Qur'an Kontemporer : Wacana Baru Berbagai Metodelogi Tafsir (Yogyakarta: Tiara Wacana, 2002), ix.

${ }^{5}$ Islam Gusmian, Khazanah Tafsir Nusantara; Dari Hermeunetika Hingga Ideologi, ( Yogyakarta: LKIS, 2013)
} 
Isu-Isu Sosial Masyarakat dalam Tafsir

Syihabuddin Alwy \& Nawal Nur Arofah

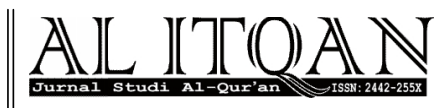

Kemudian dalam desertasinya yang berjudul 'Dialektika Tafsir Al-Qur'an Era Orde Baru" Gusmian menganalisa beberapa tafsir pada era Orde Baru dengan menguanakan teori keterpengaruhan subyek/penafsir dan ruang serta peran sosial - politik yang dirumuskan Amin Al-Khuli, teori sosiologi pengetahuan Karl Mannheim, dan pendekatan sejarah Muhammed Arkoun. Kajian yang dilakukannya menunjukkan, telah terjadi dialektika antara tafsir dan praktek politik rezim Orde Baru. Tafsir-tafsir Al-Qur'an pada era rezim Orde Baru telah mengkontestasikan praktek praktek politik rezim Orde Baru dalam tiga perspektif tafsir. Yaitu, perspektif tafsir bungkam. Dimana tafsir mengalami keberjarakan dari problem sosialpolitik rezim Orde Baru. Perspektif tafsir gincu. Dimana tafsir melakukan peneguhan atas kebijakan dan praktek politik rezim Orde Baru. Serta perspektif tafsir kritis. Dimana Tafsir melakukan kritik atas kebijakan dan praktek politik rezim orde baru. Tiga perspektif tafsir tersebut digerakkan oleh faktor basis sosial, keilmuwan dan peran sosial-politik penafsir, serta audien dan ruang publikasi tafsir. ${ }^{6}$

Dari situlah penulis ingin memcoba mendalami bagaimana sebuah kitab tafsir bisa memuat hal-hal yang bersingungan dengan kondisi sosial yang terjadi di masyarakat dengan mengkaji kitab Tafsir Tāj al Muslimīn Min Kalāmi Rabb al 'Alamīn karya K.H. Misbach Mustafa. Di mana kitab tafsir ini ditulis pada tahun 1988 - 1994 dan K.H Misbach Mustafa terkenal sebagai ulama’ yang kritis dengan isu-isu sosial yang terjadi di masyarakat.

\section{B. Biografi K.H. Misbach Mustafa dan Tafsir Täj Al-Muslimīn}

KH. Misbach Mustafa merupakan pengasuh Pondok Pesantren al-Balagh, Bangilan, Tuban, Jatim. Beliau lahir di daerah pesisir Jawa Tengah, tepatnya di kampung Sawahan, Gang Palem, Rembang tahun 1916 dengan nama Masruh. Orang tua beliau bernama H. Zaenal Mustafa dan Khadijah. ${ }^{7}$

Misbach memiliki 4 saudara, yaitu Zuhdi, Maskanah, Bisri dan terakhir Misbach sendiri. Zuhdi dan Maskanah adalah putra dari istri H. Zaenal yang pertama bernama Dakilah. Dengan kata lain Ibu Misbach yang bernama Khadidjah adalah istri kedua dari H. Zaenal. ${ }^{8}$

\footnotetext{
${ }^{6}$ Islah Gusmian, “Dialektika Tafsir Al Qur`an Era Orde Baru”, Desertasi Fakustas Ushuluddin UIN Sunan Kalijaga, Yogyakarta, 2014.

${ }^{7}$ Muhammad Nafis Misbach, Wawancara, Bangilan, 22 April 2016.

$8 \quad$ Ibid., 36.
} 
Saat ayahnya meninggal, usia Misbach terhitung masih kecil. Misbach bersama saudara-saudaranya yang lain kemudian diasuh oleh kakak tirinya yang bernama Zuhdi. Oleh karena itu, meskipun orang tua Misbach "berada" tetapi Misbach sudah mengalami hidup yang memprihatinkan sejak ditinggal ayahnya. Inilah salah satu motivasi Misbach untuk selalu menulis dan menerjemahkan kitab-kitab kuning bahkan sejak dia masih berada di pondok pesantren. Hasil karangan dan terjemahannya kemudian ia jual untuk memenuhi kebutuhan atau biaya hidup selama belajar di Pondok Pesantren. Tradisi inilah kemudian ia kembangkan hingga wafatnya. Tidak ada waktu luang bagi Misbach kecuali ia manfaatkan untuk menulis. Dari tangannya kemudian lahir karya-karya tulisan dan terjemahan kitab klasik yang sangat banyak. Tradisi menulis ini juga dikembangkan oleh kakak kandungannya bernama Bisri yang lebih dikenal dengan nama lengkap Bisri Mustafa pengarang Tafsir alIbriz li Ma'rifati al-Qur'an al-Aziz. ${ }^{9}$

K.H. Misbah Mustafa juga pernah aktif dalam dunia politik. motivasi Misbach dalam berpolitik adalah untuk berdakwah melalui partai atau Ormas. Pertama Misbach aktif di Partai NU yang saat itu masih aktif dalam kegiatan politik. Namun karena perbedaan persepsi tentang suatu masalah keagamaan akhirnya Misbach keluar. Masalah tersebut terletak pada perbedaan pandangan mengenai boleh tidaknya mendirikan BPR (Bank Perkreditan Rakyat). Misbach menganggap BPR sebagai lembaga ekonomi yang mempraktekkan riba, sehingga Misbach menganggapnya haram. Sementara NU menganggap bunga bank bukan sebagai riba sehingga tidak masalah seandainya NU mendirikannya. Perbedaan pandangan ini merupakan salah satu pemicu keluarnya Misbach dari Partai NU. ${ }^{10}$

Di masyarakat beliau juga dikenal sebagai pribadi yang tegas tanpa kompromi dalam memutuskan suatu masalah atau hukum. Tak jarang, ia berbeda pendapat dengan pemerintah Orde Baru, bahkan pernah suatu kali ia dengan mengharamkan program Keluarga Berencana dan Musabaqoh Tilawatil Qur'an (MTQ), yang menjadi program andalan Orde Baru.

Pada usia 78 tahun, tepatnya pada hari senin, 07 Dzul Qo'dah 1414 H, atau bertepatan dengan 18 April 1994 M, beliau wafat, dengan meninggalkan dua istri, lima putra beserta karyanya yang belum selesai, antara lain 6 buah kitab berbahasa Arab yang belum sempat diberi judul dan tafsir Tāj Al-Muslimīn yang sampai wafatnya baru sampai empat juz.

\footnotetext{
$9 \quad$ Ibid., 37.

${ }^{10}$ Misbach Mustafa, BPR NU dalam Tinjauan Al-Qur'an, (Tuban: tnp,1990), 12.
} 
Dari hasil pengamatan dan perjalanannya dari kampung ke kampung, Misbach melihat banyak sekali perilaku masyarakat yang menyimpang dari ajaran-ajaran al-Qur`an dan hadits. Hal ini mendorong Misbach untuk memberikan bimbingan kepada masyarakat tentang pemahaman ayat-ayat al-Qur’an agar mereka mengerti ajaran al-Qur'an sehingga perilaku mereka tidak menyimpang. Latar belakang ini kemudian memotivasi Misbach untuk menafsirkan al-Qur`an dalam sebuah kitab yang kemudian diberi nama Taj al-Muslim. Dalam kitab tafsir ini kita dapat melihat bahwa Misbach memiliki kepribadian yang sangat kuat dalam memegang sebuah pendapat berdasarkan pemahamannya terhadap al-Qur'an. Meskipun pendapat yang ia kemukakan tidak sejalan dengan pandangan umum, ia tetap berpegang pada pendiriannya karena ia berkeyakinan bahwa pendapat yang ia kemukakan sesuai dengan al-Qur`an dan hadits. ${ }^{11}$

\section{Isu-Isu Sosial dan Tafsir Al-Qur'an}

\section{Riba Bunga Bank dan Tafsir Al Baqarah Ayat 275}

Sekitar tahun 1990 ada suatu hal yang membuat K.H. Misbah Musthafa geram yaitu adanya wacana lembaga keagamaan NU berkerjasama dengan Bank Summa untuk mendirikan Bank Perkreditan Rakyat (BPR). Hal tersebut pula yang membuat beliau keluar dari partai NU sebab adanya perbedaan presepsi dalam keagamaan dan dalam politik. Pendirian bank ini memiliki sejumlah kebijakan dasar. Diantaranya NU harus mengambil porsi peningkatan taraf hidup rakyat. Sebab, di situlah peran NU dalam kehidupan bermasyarakat. Bukan orang-orang dalam NU ingin menjadi konglomerat. ${ }^{12}$ Menurut Gus Dur BPR ini telah mendapat izin dari Syuriah, dalam rapat gabungan pada 30 Mei 1990. Dalam rapat tersebut memutuskan bahwa PBNU diperkenankan mendirikan BPR dengan ketentuan dan syarat-syarat yang akan ditetapkan PB Syuriah sendiri. Dalam hal ini keputusan Syuriah PBNU bukannya menghalalkan, tapi memperkenankan adanya BPR tersebut dan ini pula adalah sikap toleran dari NU untuk menyikapi masalah Bank. ${ }^{13}$

Untuk mengegolkan ini, Katib Am (Sekretaris Umum Syuriah, pada waktu itu K. H. Ma'ruf Amin) sampai ngotot supaya ini dihalalkan. Alasan dia, sebab ada kesalahfahaman

\footnotetext{
${ }^{11}$ Wawancara dengan Putra ke-4 KH. Misbach tanggal 11 Mei 2006 di Bangilan Tuban.

${ }^{12}$ Abdurrahman Wahid, Tabayun Gus Dur., 230.

13 Ibid.,
} 


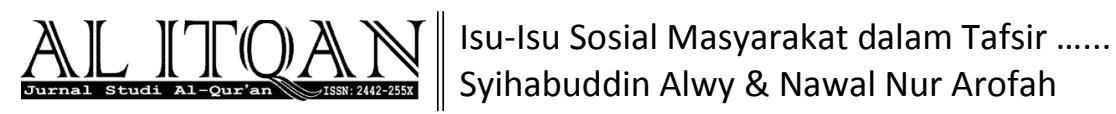

tentang memahami makna pinjaman. Pinjaman dalam bahasa Arabnya qardlun. Padahal dalam bank bukan meminjamkan uang tapi memutarkan uang. Uang si A ditaruh di bank B, untuk diputar oleh $\mathrm{C}$, ini suatu siklus. Bukan qardIun, tapi qiradl, pemutaran untuk pemanfaatan uang. Qiradl oleh agama tidak dilarang. Yang dilarang qardlun, yakni pinjaman yang membawa nilai lebih. ${ }^{14}$

Pemilihan Bank Summa atau kelompok astra sendiri menurut Gus Dur pertama, beliau melihat kelompok Astra bukan kelompok yang suka melakukan monopoli. Kedua, Bank Summa ini kuat, punya afiliasi dengan beberapa bank-bank mereka yang lain, yang berada di luar negeri serta telah tergabung dalam Summa International. Ketiga, mereka mempunyai keterkaitan dengan bank-bank besar di seluruh dunia. seperti Societe Generale di Perancis. Keempat, mereka punya strategi yang jelas dalam mengembangkan dan mengatur uang mereka. ${ }^{15}$

Peristiwa di atas dianggap mempengaruhi kiai Misbach untuk menggulirkan wacana tentang haramnya bunga bank. Pendapat ini pun dibenarkan oleh putera kiai Misbach, Nafis Misbach yang mengatakan kiai Misbach Musthofa keluar dari organisasi NU sebab terjadi perbedaan pendapat dengan Gus Dur. ${ }^{16}$ Masalah tersebut terletak pada perbedaan pandangan mengenai boleh tidaknya mendirikan BPR (Bank Perkreditan Rakyat). K.H. Misbach menganggap BPR sebagai lembaga ekonomi yang mempraktekkan riba, sehingga Misbach menganggapnya haram. Sementara NU -waktu itu ketua umumnya Gus Dur- menganggap bunga bank bukan sebagai riba sehingga tidak masalah seandainya NU mendirikannya. Berdirinya BPR tersebut diharapkan bisa meningkatkan taraf hidup rakyat.

Dalam suatu dialog yang ditulis dalam buku BPR NU Dalam Tinjauan Al Qur'an kiai Misbach berpadapat meskipun diantara ulama ada yang mengatakan halal dan syubhat ia tetap berpegang pada pendapat yang mengatakan haram. Sebab, menurut beliau sudah di jelaskan dalam al Qur`an al Baqarah ayat 275 :

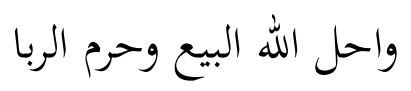

"Allah Menghalalkan jual beli dan mengharamkan riba"

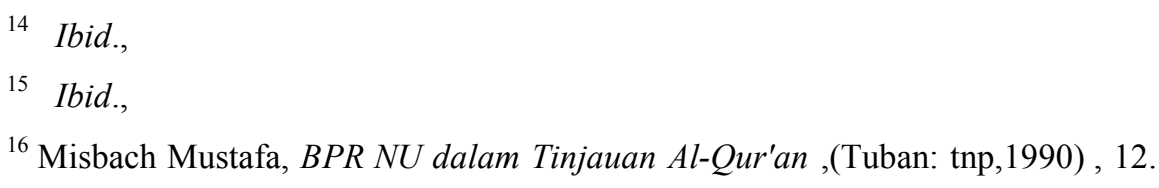


Isu-Isu Sosial Masyarakat dalam Tafsi

Syihabuddin Alwy \& Nawal Nur Arofah

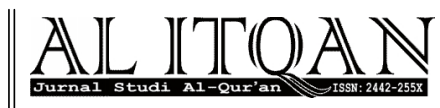

Dalam sebuah hadis Nabi Muhammad Șalla Allah 'Alaihy Wa Sallam bersabda:

$$
\text { كل قرض جر نفعا للمقرض فهو ربا }
$$

" Tiap-tiap hutang yang menarik manfaat bagi orang yang memberi hutang itu riba, yakni sama dengan akad riba."

Dalam hadis lain:

$$
\text { لعل الله اكل الربا و موكله و كاتبه و مانع الصدقة }
$$

"Semoga Allah melaknat orang yang makan riba, orang yang membeli riba dan penulis riba serta orang yang tidak mau mengelurkan zakat. (hadis riwayat nasa'i dan Ali)

Nash Al-Qur`an dan hadis di ataslah yang menjadi pedoman beliau dalam mengambil kesimpulan haramnya BPR atau Bank pada umumnya. Hal ini pun tanpa terkecuali maksudnya meskipun dalam hadis lain nabi besabda:

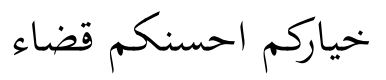

“ Kamu sekalian yang paling bagus ialah orang yang paling bagus membayar hutang, yakni dengan memberikan kelebihan".

Selain dalam buku BPR NU Dalam Tinjauan Al Qur-an beliau juga menulis permasalahan riba ini dalam kitab Tafsir Tāj Muslimīn. Di mana pembahasan tersebut terdapat dalam surat al Baqarah ayat 275 :

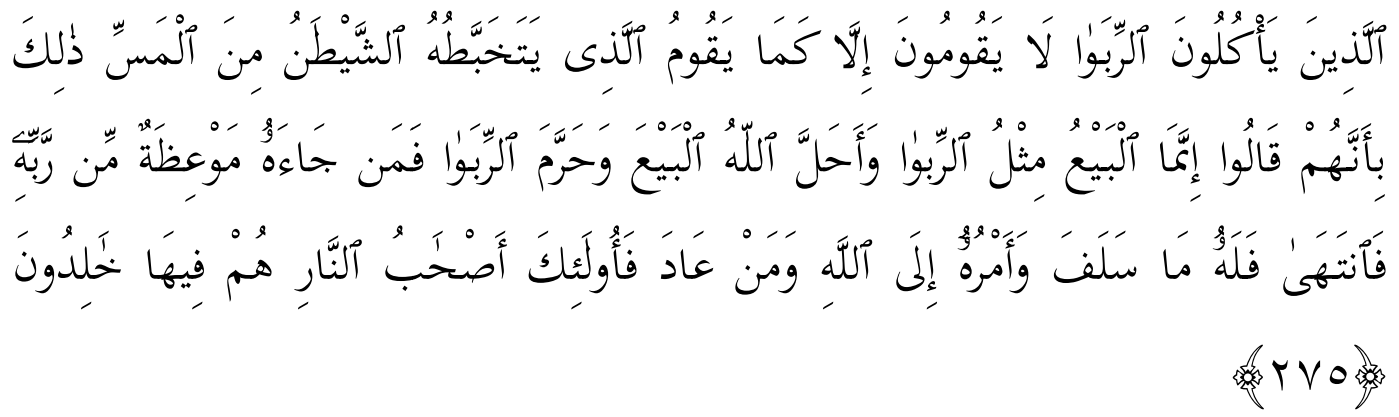

"Wong-wong kang mangan riba tegese wong kang pada serawung gawe ganti riba besuk ono nang dino kiamat ora biso ngadek kejaba kaya ngadeke wong kang di muntang-mantingake dining syaitan kerana edan. Kang mengkono iku sebab wong-wong iku podo ngucap, podo niqadake yen riba iku pada karo dodolAllah ngalalake dodol lan ngaromake riba-sopo-sopo wong kang nompo pitutur sangking pangerane nuli gelem mareni sangkin olehe serawung gawe ganti riba, opo kang wus lumaku kena dimiliki lan sopo-sopo wong kang bali ngelakoake riba, wong-wong iku bakal dadi penduduk neraka sarana langeng”. 
(Orang-orang yang memakan harta riba yakni orang yang berkumpul membuat pengganti riba besok ketika hari kiamat tidak bisa berdiri kecuali seperti berdirinya orang yang dibingungkan oleh syaitan sebab gila. Yang seperti itu sebab orang-orang tersebut mengatakan, menyakini bahwa riba itu sama seperti jual beli. -Allah menghalalkan jual beli dan mengharamkan riba- barang siapa yang menerima nasihat dari Allah, kemudian mau berhenti dari bergelut dengan membuat penganti riba, apa yang sudah berjalan bisa dimiliki dan barang siapa yang kembali melakukan riba, orang-orang itu akan jadi penduduk neraka kekal di dalamnya.)

Dalam penafsiranya beliau di atas, kita bisa melihat yang terkena dampak dari ayat di atas bukan hanya orang yang memakan riba saja malainkan orang yang berkumpul dan membuat kesepakan penganti riba.

Sekarang siapakan yang beliau maksud dengan orang yang berkumpul dan membuat pengganti riba tersebut. Melihat kembali kepada isu sosial di atas Bahwa pada waktu itu para pimpinan NU berkerjasama dengan bank summa untuk mendirikan 250 Bank Perkreditan Rakyat (BPR). Kesepakatan ini pun merupakan hasil rapat gabungan NU pada 30 mei 1990. Pada rapat tersebut menurut Gus Dur selaku Ketua Umum PBNU, dewan syuri'ah NU memberikan izin kepada PBNU untuk mendirikan BPR NU.

Jadi, bisa dikatakan bahwa yang dimaksud wong kang pada serawung gawe ganti riba adalah para pimpinan NU tersebut. Di mana mereka membuat penganti praktik riba yaitu bank BPR. Padahal mereka sendiri sudah tahu bahwa praktek yang terjadi dalam transaksi bank menyerupai riba.

Kemudian pada bagian lain ia menjelaskan tentang persamaan riba dan bunga bank. Dalam tafsirnya beliau menjalaskan

\begin{abstract}
"Ana ing tafsire Imam al-Razi diterangake: riba nasi'ah ya iku kang mashur lan terkenal ana ing zaman jahiliyah wong-wong pada zaman iku podo ngutangi arto kelawan syarat saben sak wulan kudu ngawehi keuntungan kang den tentuake, sedang arto pokok tetep- nuli kapan wus tempone mbayar - wong mau nuntut arto pokok supoyo dibalekake yen ora biso ambayar arto pokok lan tempone diundakake, (umpamane arto pokok sewu maleh sewu satus) saben wulan tetep ambayar, tempone diundaake setengah tahun. Lan mengkene saktruse iyo iki riba kang lumaku ing zaman jahiliyah.- Ing zaman saiki kang lumaku nitipake duwit ono ing bank ing kuto. Saben wulan bungane utowo anakane dijupuk kanggo ngongkosi anake kang sekolah ing kuto kunu, iki kang lumaku ing zaman jahiliyah modern."
\end{abstract}

Dalam penafsiran tersebut Misbach menjelaskan tentang bagaimana bentuk persamaan riba nasi'ah yang terjadi pada masa jahiliyah klasik dan di masa modern saat ini. Di mana 
Isu-Isu Sosial Masyarakat dalam Tafsi

Syihabuddin Alwy \& Nawal Nur Arofah

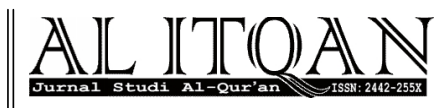

pada saat ini bagi Misbach praktek riba nasi'ah adalah transaksi simpan pinjam di bank. Meskipun terkadang ada yang mengangap kedua hal tersebut tidak bisa di samakan sebab dalam bank tidak terdapat akad seperti dalam riba.

"Kadang-kadang kang gawe alasan, yen kang mengkuno iku ora ono akaddewene namung nitip lan alasan-alasan liyane, nanging wong-wong kang ngene iki lali yen

$$
\text { العادة المطردة تنزل منزلة الشرط }
$$

"Artine pengadatan kang wus lumaku iku manggon ana ing pangonane syarat (janji) - mestine wong kang tembunge titip duwit ana ing bank iku wos podo ngerti pengumumane bank sopo kang nitip arto sakmene, bungane sakmeneumpamane ana siji kampung ono tukang potong rambut kang wus kaprah saben ono wongkang cukur mesti bayar sewu rupiah - nuli Saridin potong rambut bareng rampung metu ora bayar karena ora ono akad-akadan ora ana janjian bayar sewu-Sariden temtu disalahake wong akeh-ringkese riba iku ono warno loro: riba fadli lan riba nasa'- dene riba utang iku kelebu riba fadli lan ora kudu podo jenise utawa ukurane yaiku saben-saben utang kang bisa narik kemanfaatan marang wong kang ngutangi koyo utang satus ambayar satus sepuluh. Ing mongso iki macem-maceme utang-utang kang agawe keutuntungan marang wong kang ngutangi iku akeh banget."

\section{Respon Terhadap Program Keluarga Berencana}

Kiai Misbach Mustafa merupakan salah satu ulama yang mengkritik tentang adanya pembatasan populasi yang dicanangkan oleh pemerintah Orde Baru. Hal ini pula yang menurut Muhammad Nafis Misbach menyebabkan beliau diseret ke pengadilan dengan tuduhan sebagai pihak yang melawan kebijakan pemerintah. ${ }^{17}$

Pada tahun 1961 penduduk negara Indonesia 67,1 juta jiwa dan pada tahun 1971 penduduk Indonesia telah mencapai 119,2 juta jiwa. Dalam artian dalam kurun waktu 10 tahun penduduk negara Indonesia bertambah 22,1 juta jiwa. Sungguh pertumbuhan yang signifikan. Kondisi ini jelas menimbulkan dua sisi yang berbeda. Disatu sisi kondisi tersebut bisa menjadi salah satu kekuatan yang besar untuk Indonesia. Tetapi di satu sisi kondisi tersebut menyebabkan beban negara menjadi semakin besar. Selain menjadi beban negara juga menimbulkan permasalahan lain. Banyaknya jumlah penduduk yang tidak disertai dengan ketersediaan lapangan pekerjaan yang mampu menampung seluruh angkatan kerja

\footnotetext{
${ }^{17}$ Muhammad Nafis Misbach, Wawancara, Bangilan, 22 April 2016
} 
bisa menimbulkan pengangguran, kriminalitas, yang bersinggungan pula dengan rusaknya moralitas masyarakat.

Karena berhubungan dengan tinggi rendahnya beban negara untuk memberikan penghidupan yang layak kepada setiap warga negaranya, maka pemerintah memberikan serangkaian usaha untuk menekan laju pertumbuhan penduduk agar tidak terjadi ledakan penduduk yang lebih besar. Salah satu cara yang dilakukan oleh pemerintah adalah dengan menggalakkan program KB (Keluarga Berencana). Program KB pertama kali dilaksanakan pada masa pemerintahan Soeharto yaitu saat Orde Baru. Melalui KB masyarakat diharuskan untuk membatasi jumlah kelahiran anak, yaitu setiap keluarga memiliki maksimal dua anak. Tidak tanggung-tanggung, KB diberlakukan kepada seluruh lapisan masyarakat, dari lapisan bawah hingga lapisan atas dalam masyarakat.

Di Indonesia progam keluarga berencana (KB) telah dirintis sejak tahun 1953. Dan pada tahun 1957 berdiri sebuah organisasi swasta bernama perkumpulan Keluarga Berencana Indonesia (PKBI) yang berpusat di Jakarta, di antara pendirinya adalah Prof. Sarwono Prawiroharjo dan Prof. Judono. ${ }^{18}$

Kegiatan mereka dilaksanakan secara diam-diam. Sebab, pemerintahan Soekarno saat itu mengangap belum waktunya menjadiakan program $\mathrm{KB}$ sebagai program nasional. Presiden Soekarno berkata " we can feed 250 mollion people. The more people in Indonesia, the more voice in the world"' Kita dapat memberi makan 250 juta rakyat, lebih banyak rakyat Indonesia lebih besar suara Indonesia di dunia). ${ }^{19}$ Hal ini yang menunjukan sikap negatif pemerintahan waktu itu terhadap Keluarga Berencana (KB).

Sejak lahirnya orde baru tahun 1966, pemerintah mulai menaruh perhatian terhadap persoalan kependudukan. Tahun 1967 Presiden Soeharto ikut menandatangani deklarasi kependudukan dunia. Sejak itu pemerintah mengambil alih tanggung jawab pelaksanaan keluarga berencana melalui Inpres No. 20/1968 dengan membentuk Lembaga Keluarga Berencana Nasional (LKBN) yang masih berstatus semi pemerintah. ${ }^{20}$

Kemudian barulah pada tahun 1970 pemerintah mengambil kebijakan bahwa KB merupakan bagian integral dari pembangunan nasional. Maka dibentuk Badan Koordinasi

\footnotetext{
${ }^{18}$ Shiddiq Amien, Keluarga Berencana; Dalam Pandangan Islam ( Bandung: PERSIS, 2001, ) 3.

19 Ibid., 4.

20 Ibid.,
} 
Isu-Isu Sosial Masyarakat dalam Tafsi

Syihabuddin Alwy \& Nawal Nur Arofah

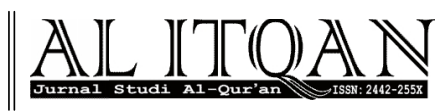

Keluarga Berencana Nasional (BKKBN) yang berstatus lembaga pemerintah dengan fungsi:

a. Membantu presiden dalam menetapkan kebijakan pemerintah di bidang keluarga berencana.

b. Mengkordinasi pelaksanaan keluarga berencana yang dilakukan oleh unit-unit KB.

Dan pada akhirnya pada tahun 1972 keluar Kepres No. 33/1972 di mana status BKKBN menjadi lembaga non Departemen yang berkedudukan lansung di bawah presiden.

Akan tetapi, hal tersebut tidak terlepas dari pro dan kontra. Salah satu pihak yang menentang adalah kiai Misbach Mustafa. Bentuk penentangan ini penulis misalnya temukan dalam kitab tafsir Tāj Muslimīn surat al-Baqarah ayat 49 yang berbunyi:

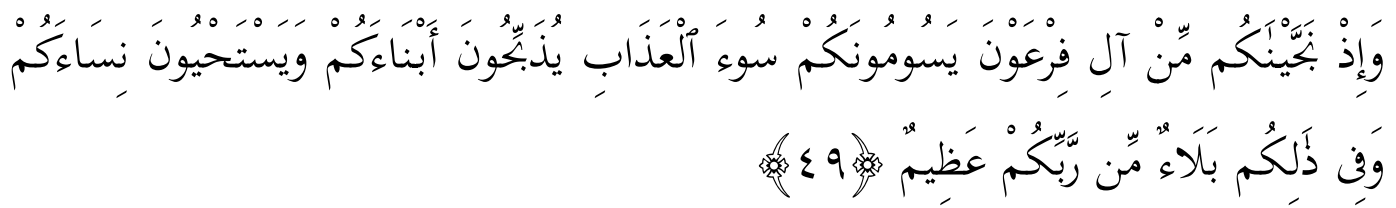

"Artine Ayat: hai Bani Israil! hai wong yahudi madinah! ilengo nikmat kang wos ingsung paringake marang lelehure nira. Zamane ingsung nyelametake leluhure nira sangking penganiyayaane raja Firaun lan kaume. Iku Firaun tansah nyiksa lelehurmu terus menerus. Podo nyembelih anak-anake leluhur, podo ngurupake wong wadon leluhur niro. Kedadian kang mengkono iku ngandung kenikmatan kang banget gedhene sangking pengeran nira. Sebab, umpomo leluhur nira ora di selametake deneng Allah tentu podo mati lan ora nurunake turunan hingga sira kabeh iki. Kedadiyan ingkang mengkono iku ngandung ujian gedhi sangking Pengerane nira kabeh"

(Arti ayat: hai bani Israil! hai orang Yahudi Madinah! ingatlah nikmat yang sudah saya berikan kepada nenek moyangmu. Zaman ketika menyelamatkan nenek moyangmu dari kekejaman raja Fir'aun. Raja Fir'aun terus-menerus menyiksa leluhur kalian. Kejadian yang seperti itu mengandung kenikmatan yang sangat besar dari Tuhanmu. Sebab, seumpama leluhurmu tidak di selamatkan oleh Allah tentu mereka meninggal dunia dan tidak memberikan keturunan seperti kalian saat ini. Kejadian yang seperti itu mengandung ujian besar dari Tuhanmu.)

Kemudian manakah hal yang membicarakan tentang konspirasi keluarga berencana. Dalam salah satu penafsiranya beliau menceritakan sebuah kisah pada zaman raja Firaun (Musab bin Walid) pada saat kepemimpinannya, ia melihat di negara Mesir jumlah golongan Qibti (penduduk asli Mesir) dalam pertumbuhannya, berbanding terbalik dengan golongan Bani Israil. Golongan Qibti sulit tumbuh sedangkan jumlah orang bani Israil lebih cepat sekali perkembangannya pada waktu itu kelompok bani Israil telah mencapai kurang lebih 2.000 jiwa. Melihat fenomena tersebut raja Firaun khawatir jika kelompok Bani Israil akan 
melakukan kudeta terhadap pemerintah. Karena jumlah dari orang-orang Qibti sedikit pastilah mereka akan kalah, sehingga kekuasaan pemerintah akan berpindah tanggan kepada kelompok Bani Israil.

Untuk mencegah hal tersebut Raja Firaun dan para pimpinan negara membuat suatu siasat, bagaimana agar jumlah Bani Israil menurun. Akhirnya mereka memutuskan untuk membuat kerja paksa terhadap Bani Israil, sedangkan golongan Qibti bebas dari hal tersebut. ${ }^{21}$ sebab, mereka mempunyai suatu anggapan apabila orang diperas tenaganya, di buat susah hatinya, maka mereka akan sulit untuk membuat katurunan.

Akan tetapi, hal tersebut berbanding terbalik dengan apa yang difikirkan oleh Firuan dan jajaran pimpinan negara Mesir. Kelahiran bukan malah berkurang, akan tetapi malah menjadi lebih banyak dibandingkan sebelum adanya kerja paksa tersebut.

Setelah bercerita panjang lebar tentang kisah Firaun, beliau mengingatkan tentang suatu kaidah sejarah.

$$
\text { التريخ يعيد نفسه }
$$

“Sejarah itu pasti akan kembali kepada muatannya".

Dalam hal ini beliau ingin mengingatkan umat untuk berhati-hati. Sebab, bisa jadi peristiwa yang terjadi pada zaman Firaun tersebut akan terulang di masa sekarang.

Sehingga beliau mengingatkan jika pada zaman Firaun terjadi suatu pembatasan kelahiran yang didasari oleh unsur politik. Tidak menutup kemungkinan pula, hal ini akan terulang pada zaman sekarang. Bisa jadi pembatasan kelahiran yang terjadi pada zaman sekarang di dasari oleh unsur politik. Meskipun pada dasarnya hal tersebut di atas dinamakan untuk kemaslahatan rumah tangga atau persoalan kekurangan bahan makanan, dan lain-lain.

\section{Membaca Basamalah Dalam Shalat}

Seperti yang kita ketahui dalam kitab-kitab Fiqh madzhab Syafi'i dijelaskan bahwa membaca surat Al-Fatihah merupakan salah satu rukun dalam shalat dan basmalah merupakan ayat dari surat Al-Fatihah. ${ }^{22}$

\footnotetext{
21 Ibid., 188.

${ }^{22}$ Muhammad bin Qāsim al-Ghazī, Fathu al-Qarīb al-Muj̄̄b, ( Surabaya: Haromaīn, 2005), 13.
} 
Isu-Isu Sosial Masyarakat dalam Tafsi

Syihabuddin Alwy \& Nawal Nur Arofah

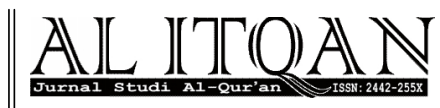

Akan tetapi hal ini merupakan sebuah khilafiyyah dalam masalah fiqih. Sebagian ulama' berpendapat bahwa basmalah merupakan ayat dari surta al-Fatihah, akan tetapi sebagian lagi mengatakan bahwa basmalah bukan ayat dari surat al-Fatihah.

Permasalahan khilafiyyah seperti ini terkadang menjadi suatu problem bagi masyarakat yang awam. Apalagi untuk kalangan yang fanatik pastilah akan menyalahkan satu sama lain.

Di Indonesia sendiri sejak awal abad ke 20 ada suatu gap antara dua organisasi kegaamaan yaitu NU dan Muhammadiyah. Dua organisasi ini merupakan dua organisasi terbesar di Indonesia. Salah satu yang menjadi perdebatan mereka adalah pembacaan basmalah dalam shalat.

Nahdhotul Ulama' yang fiqhnya bermadzab Syafi'i menganggap bahwa basmalah adalah bagian dari surat al-Fatihah dan siapa yang shalat tidak membaca basmalah, maka shalatnya tidak sah. Cara membacanya pun disunahkan keras pada saat shalat-shalat yang dianjurkan membaca dengan keras. Sedangkan Muhamadiyyah menetapakan pandangan yang berbeda.

Dalam analisa penulis hal tersebutlah yang membuat beliau Misbach Mustafa memberikan suatu penjelasan tentang persoalan keagamaan tersebut. Hal ini pun kemudian beliau utarakan dalam karyanya Tafsir Tāj Muslimīn dan beberapa karya yang lain salah satunya adalah kitab al Nur al Mubbīn fi àdābi al Muslihīn. ${ }^{23}$

Dalam kitab tersebut beliau juga menyebutkan bahwa permasalahan ini bukan suatu hal baru dalam Islam. Khilafiyyah tersebut sudah menjadi perdebatan para mujtahid-mujtahid zaman dahulu di mana mereka dalam berpendapat berdasarkan dalil-dalil yang kuat.

Menurut kiai Misbach khilafiyyah ini menjadi ramai kembali setelah munculnya beberapa kelompok keagamaan di Indonesia. Ada suatu kelompok yang menamakan dirinya sebagai Majlis Tarjih (semacam dewan fatwa di Muhammadiyah) yang menetapkan satu hukum yang dianggap lebih kuat dari yang lainya menentang bahwa basmalah sebagian dari surat al-Fatihah. Dalam hal ini mereka juga mengutarakan suatu dalil yang dianggap lebih kuat dari dalil yang ada dan diharapkan dalil tersebut bisa mempengaruhi para orang Islam di Indonesia yang bermadzhab Syafi'i. Selain itu pula mereka tidak mengakui ketetapan ijtihad

\footnotetext{
${ }^{23}$ K.H. Misbach Mustafa, al Nur al Mubbīn fi ādābi al Muslihīn.(Bangilan: Maktabah al Balaq, 1992), 102.
} 
ulama-ulama salaf. Sehingga dengan begitu perkumpulan tersebut tidak sadar bahwa dirinya telah membuat suatu madzhab baru dan hasil dari tarjih atau ijtihad mereka diikuti oleh para anggota kelompoknya. ${ }^{24}$

Sampai disini kita bisa melihat bahwa Misbach Mustofa selalu merespon hal-hal yang menjadi permaslahan dalam masyarakat. Respon tersebut menurut Muhammad Nafis Misbach sebagai bentuk kehati-hatian beliau dalam rangka menjaga umat Islam dari perpecahan dan kesesatan. $^{25}$

Hal ini belaiu lakukan sebab status beliau yang merupakan seorang ulama. Di mana beliau harus meluruskan suatu permasalahan umat apalagi itu adalah permasalahaan agama. Selain status beliau sebagai seorang ulama, latar belakangan Nahdhatul Ulama (NU) juga mempengaruhi beliau dalam merespon isu sosial tersebut.

Meskipun dalam kesimpulanya beliau lebih mementingkan persatuan umat, akan tetapi dalam kesimpulan tersebut beliau mengkritik kelompok Majlis Tarjih (Muhamadiyah). Dalam hal ini Beliau mempertanyakan kualitas keilmuwan dari ahli tarjih kelompok tersebut. Sebab, yang namanya ahli tarjih selain harus mempunyai ilmu yang lengkap, kecerdasan di atas rata-rata, dan amal dan ketaqwaan kepada Allah yang tinggi, mereka juga harus memiliki akhlaq dan ibadah yang bisa mencerahkan dunia. ${ }^{26}$ Menurut beliau hal-hal tersebut sangat jauh dan bisa-bisa tidak di miliki oleh Majlis Tarjih tersebut. Ia bahkan menyebutnya bagaikan langit dan bumi. ${ }^{27}$

\section{Bidah pengeras Suara}

Kemudian isu sosial selanjutnya adalah tentang pengeras suara. Memang Tafsir Tāj Muslimīn bukan satu-satunya karya Misbach Mustafa yang menyinggung tentang penggunaan pengeras suara dalam ibadah. Penulis menemukan beberapa karya beliau yang juga terdapat pembahasan tentang penggunaan pengeras suara. Dalam menyikapi persoalan ini Misbach Mustafa tampaknya merupakan orang yang memegang teguh pendapat. Hampir dalam setiap karyanya ketika membahas dzikir pasti juga akan memasukan masalah penggunaan pengeras

\footnotetext{
${ }^{24}$ Ibid., 102-103.

${ }^{25}$ Nafis, Wawancara,

${ }^{26}$ K.H. Misbach Mustofa, al Nur al Mubin, 103.

27 Ibid., 103.
} 
Isu-Isu Sosial Masyarakat dalam Tafsi

Syihabuddin Alwy \& Nawal Nur Arofah

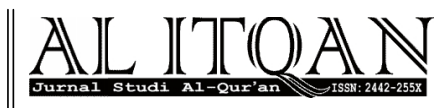

suara. Dan kesimpulan akhirnya beliau menghukumi pengunaan pengeras suara dalam ibadah adalah bid'ah.

Dalam penelusuran penulis ada beberapa hal yang mendasari beliau dalam mengeluarkan fatwa tersebut. Diantaranya adalah pada tahun 1978 tepatnya pada tanggal 17 Juli 1978 Direktur Jendral Bimbingan Masyarakat (BIMAS) Islam mengeluarkan suatu intruksi tentang tuntunan penggunaan pengeras suara di Masjid, Langgar, dan Mushola. Hal tersebut supaya tercapainya sasaran dakwah/penyampaian agama kepada masyarakat yang lebih luas baik di dalam maupun di luar masjid, langgar dan mushola. Sehingga jamaah atau umat Islam yang jauh letaknya dari masjid, langgar, atau mushola serentak dapat mendengar panggilan atau pesan dakwah walaupun tidak hadir dalam masjid.

Selain itu penggunaan pengeras suara tersebut bisa membuat jamaah yang jauh dari imam, mubaligh, atau guru yang menyampaikan tabligh bisa mendengar lebih jelas sebagai mana yang duduk dengan imam atau mubaligh tersebut.

Akan tetapi, alasan tersebut ditolak oleh K.H. Misbach Mustafa, seperti apa yang beliau sampaikan dalam Tāj Muslimīn dalam surat al Baqarah ayat 186:

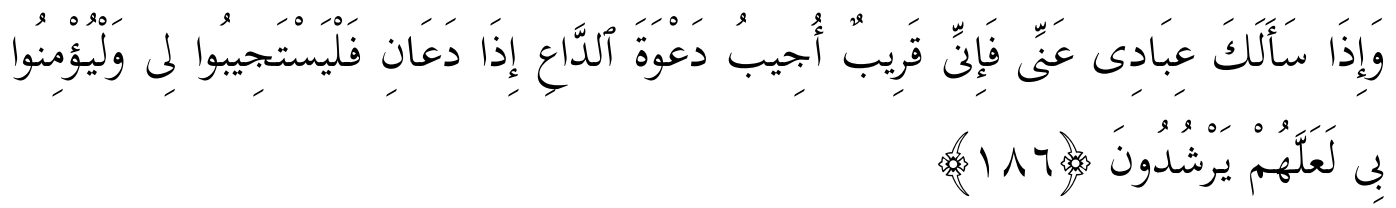

"Hai Muhammad! yen kawulo-kawulo ingsun podo takon marang sira sangking kedudukan ingsun supoyo sira jawab: ingsun iku parek marang kawulo iku, ingsun nyembadani pengundang-ngundange sopo bahe wong kang ngundangngundang ingsun nalika dewene ngundang-ngundang ingsun. Songko iku, poro kawulo ingsun supoyo nyembadani ingsun yen ingsun ngajak dewene supayo taat marang ingsun lan podo nyempurnaake olehe iman marang ingsun supoyo podo oleh dalam kang bener keteng karo perkoro donya lan akhirate."

Dalam penafsirannya Misbach juga memaparkan asbab nuzul dari ayat tersebut. salah satu riwayat menyebutkan bahwa Nabi Muhammad Șalla Allah 'Alaihy Wa Sallam itu ketika pulang dari perang Khaibar. "Kerunggu para sahabat podo ngundang-ngundang Allah Ta'ala (doa) dengan suara yang keras sehingga beliau pun dawuh sebagai berikut, " Sira kabeh iku ora ngudang-ngundang pengeran kang kopok utowo pengeran kang samar.” Terjemahan: Mendengar para sahabat memanggil-manggil Tuhan (berdoa) dengan suara yang keras, Nabipun bersabda, "Kalian tidak sedang menyeru kepada Tuhan yang tuli atau tidak melihat". 
Jadi, berdasarkan hadis di atas Misbach berkesimpulan bahwa tidak sepantasnya seseorang ketika menjalankan ibadah dengan mengeraskan suara. Kecuali telah ada ketentuan syara' yang terdapat pada shalat jahriyah yaitu sekiranya orang yang ada di dekatnya itu bisa mendengarkan suaranya.

Akan tetapi menurut beliau dawuh Rasulullah Șalla Allah 'Alaihy Wa Sallam tersebut oleh orang Islam zaman sekarang sudah tidak dipedulikan lagi. Seluruh masjid ada pengeras suara, shalat, do'a, tahlil, dan membaca shalawat pun mengunakan pengeras suara. Kemudian Beliau mempertanyakan apakah orang Islam sekarang ini mengangap Allah itu tuli, sudah tua, dan ketika tidak mengunakan pengeras suara Tuhan tidak mendengar. Dalam hal ini ia berkomentar, "Nanging ana ing zaman saiki, dawuh Rasul kang mengkene iki wus ora di gubris deneng para muslimin. Kabeh masjid ana pengeras suara. Shalat uga ngango pengeras suara" 28

Dalam keterangannya Misbach juga menyebutkan awal mula adanya wacana pengunaan pengeras suara dalam ibadah. Menurutnya semua ini adalah hasil gagasan dari orang-orang yang mengaku sebagai seorang ulama' atau mengangap dirinya salah satu peminpin atau intelek muslim. Perbuatan tersebut menurut beliau termasuk perbuatan maksiat, semua ulama dan pemimpin intelek itu akan menangung dosa besar. Sebab menurut beliau ada hadis Nabi yang berbunyi:

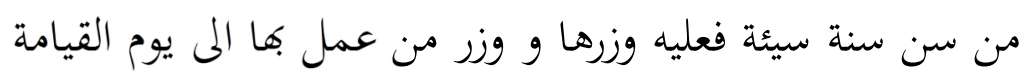

Artinya: "Barang siapa yang memulai perbuatan jelek, maka orang tersebut akan mendapat dosa perbuatan jelek itu dan dosanya orang yang menjalankan perbuatan jelek tersebut hingga hari kiamat."

\section{Analisis Masuknya Isu Sosial Dalam Tafsir Täj Muslimīn}

\section{Pencatutan Nama}

Di atas di sudah dijelaskan bahwa Misbach Mustafa merupakan tokoh yang menolak dan tidak setuju dengan adanya bank. Beliau menganggap bank merupakan instansi yang mempraktekan transaksi riba. Akan tetapi, ketika PBNU sepakat mendirikan BPR NU sebagai salah seorang tokoh NU, Misbach takut dianggap sebagai tokoh yang menyetujui berdirinya

\footnotetext{
28 Ibid., 2: 586.
} 
Isu-Isu Sosial Masyarakat dalam Tafsi

Syihabuddin Alwy \& Nawal Nur Arofah

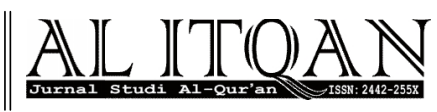

BPR NU. ${ }^{29}$ Padahal beliau sudah menegaskan menolak pendirian BPR NU tersebut dan keluar dari organisasi NU sebab kebijakan organisasi tersebut tidak sesuai dengan pandangannya.

Sehingga Misbach dalam hal ini mencoba untuk mengklarifikasi dan menegaskan kepada publik atau orang-orang yang bersankutan bahwa beliau tidak ada sangkutpautnya dengan pendirian BPR NU tersebut dan beliau merupakan orang yang menolak adanya bank tersebut.

Bentuk klarifikasi dan penegasan tersebut ia utarakan dalam beberapa tulisannya, di antaranya melalui buku BPR NU Dalam Tinjauan Al Qur'an, Tafsir Al Iklil dan Tafsir Tāj Muslimin.

\section{Bertentangannya Isu Sosial dengan Al-Qur'an dan Sunah}

Kitab Tafsir Tāj Muslimīn ditulis oleh. Misbach Mustafa karena keprihatinan beliau di mana orang-orang Islam mengaku bahwa al-Qur`an sebagai kitab petunjuk, tetapi mereka malas mendalami isi daripada al-Qur`an itu sendiri. Menurutnya para santri dan anak sekolah, segera melupakan apa yang telah didapat dari pondok dan sekolahnya. Sehingga dalam kehidupannya sehari-hari tindakan-tindakan mereka kurang bermanfaat bagi dirinya sendiri karena tidak sesuai dengan tuntunan al-Qur`an. Akibatnya, banyak orang Islam dalam menjalankan perintah agamanya sekedar ikut-ikutan. ${ }^{30}$ Dan kadang mereka tidak tahu bahwa apa yang mereka jalankan itu bertentangan dengan al-Qur'an dan Sunah.

Termasuk dalam kasus riba bunga bank dan pengunaan pengeras suara. Dalam kasus riba bunga karena menurut Misbach telah dijelaskan dalam al-Qur`an surat al Baqarah ayat 275 Allah bersabda:

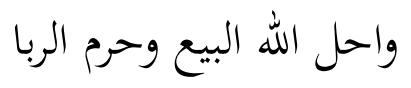

"Allah Menghalalkan jual beli dan mengharamkan riba"

Dalam sebuah hadis Nabi Muhammad Șalla Allah 'Alaihy Wa Sallam bersabda:

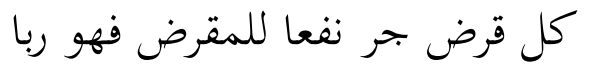

\footnotetext{
${ }^{29}$ K.H. Muhammad Nafis Misbach, Wawancara, Bangilan, 22 April 2016.

${ }^{30}$ K. H. Misbach Mustafa, Tafsir Taj al-Muslimin Min Kalami Robbi al Alamin, (Bangilan: Majlis Ta'lif wa al Khatath, 1990), 1:3.
} 
“ Tiap-tiap hutang yang menarik manfaat bagi orang yang memberi hutang itu riba, yakni sama dengan akad riba."

Dalam hadis lain:

$$
\text { لعل الله اكل الربا و موكله و كاتبه و مانع الصدقة }
$$

" Semoga Allah melaknat orang yang makan riba, orang yang membeli riba dan penulis riba serta orang yang tidak mau mengelurkan zakat. (hadis riwayat nasa'i dan Ali)

Dari sini bagi Misbach sudah jelas bahwa yang namanya riba itu haram dan di laknat oleh Allah. Maka jika ada orang yang menjalankan riba sama saja dia menentang kententuan al-Qur`an dan Sunah Nabi.

Kemudian mengapa bunga bank dikategorikan seperti riba, ia memberi alasan sebab bunga bank adalah keuntungan yang diambil oleh bank dan biasanya ditetapkan dalam bentuk persentase seperti $5 \%$ atau $10 \%$ dalam jangka waktu bulanan atau tahunan terhitung dari jumlah pinjaman yang diambil nasabah.

Bunga bank digunakan oleh bank-bank konvensional sedangkan bank syariah biasanya menggunakan istilah margin keuntungan. Bagi bank konvensional, bunga bank menjadi tulang punggung untuk menanggung biaya operasional dan menarik keuntungan. Selain itu bunga bank memiliki beberapa manfaat bagi bank dan nasabah seperti berikut ini:

a. Bunga pinjaman merupakan balas jasa yang diberikan nasabah kepada bank atas produk bank yang dibeli nasabah,

b. Bunga simpanan adalah harga yang harus dibayar bank kepada nasabah (yang memiliki simpanan), selain itu bunga juga merupakan harga yang harus dibayar oleh nasabah kepada bank (bagi nasabah yang memperoleh pinjaman),

Jadi menurut beliau hal tersebut tidak ada bedanya dengan riba di mana ada kelebihan yang diberikan atau yang harus dibayar ketika terjadi transaksi dalam bank.

Kemudian sama halnya dalam kasus pengunaan pengeras suara dalam penjelasanya beliau mengutip pada suatu hadis Nabi Muhammad SAW ketika pulang dari perang Khaibar, “ Kerunggu para sahabat podo ngundang-ngundang Allah ta'ala (doa) dengan suara yang keras sehingga beliau pun dawuh sebagai berikut "Sira kabeh iku ora ngudang-ngundang 
pengeran kang kopok utowo pengeran kang samar." (kamu semua itu tidak memanggil Tuhan yang tuli atau Tuhan samar).

Dalam hal ini ia bahkan menantang para ulama, intelek muslim, dan para pemimpin yang mendukung penggunaan pengeras suara di masjid-masjid untuk menyebutkan dalil nash al-Qur`an maupun Hadis Nabi. Jika ada yang bisa menyebutkan, maka beliau pun akan mensyi'arkan pengunaan pengeras suara di masjid-masjid.

\section{Menjaga Keutuhan Masyarakat}

Selanjutnya masalah pembacaan Basmalah dalam shalat yang merupakan isu yang sangat familiar di masyakat. Seperti yang kita ketahui di atas di mana di Indonesia sejak awal abad ke-20 ada gap antara dua organisasi kegaamaan yaitu NU dan Muhammadiyah. Dua organisasi ini merupakan dua organisasi terbesar di Indonesia. Salah satu yang menjadi problem mereka adalah pembacaan basmalah dalam shalat.

Nahdhotul Ulama' yang fiqhnya bermadzab Syafi'i menganggap bahwa basmalah adalah bagian dari surat al-Fatihah dan siapa yang shalat tidak membaca basmalah, maka shalatnya tidak sah. Cara membacanya pun disunahkan keras pada saat shalat-shalat yang dianjurkan membaca dengan keras. Sedangkan golongan Muhamadiyyah yang pada tahun 1925 dua tahun sepeningalan Kiai Dahlan, Muhammadiyah dinilai telah berubah. Masuknya ajaran Wahhabi dalam tubuh Muhamadiyah ikut pula berperan dalam mengubah sikap Muhamadiyah. Salah satunya adalah salah satunya adalah imam shalat tidak membaca "Bismillah" pada permulaan surat al-Fatihah dan juga tidak membaca qunut dalam shalat subuh. ${ }^{31}$

Pembacaan basmalah dalam permulaan surat al Fatihah memang merupakan sebuah khilafiyah yang terjadi sejak masa ulama-ulama terdahulu. Akibat perkara khilafiyah tersebut dikhawatirkan akan timbul suatu pertikaian antar kelompok agama di mana mereka saling menyalahkan jika praktek shalat mereka tidak sah.

Demi menghindari hal tersebut tampaknya kiai Misbach mencoba untuk menjelaskan melalui karya-karyanya salah satunya adalah tafsir Tāj Muslimin. Di mana dalam penafsiranya Misbach menjelaskan bahwa hal tersebut merupakan persoalan khilafiayah yang tidak harus di perdebatkan apa lagi sampai membuat perpecahan dalam tubuh umat Islam.

\footnotetext{
${ }^{31}$ Muhammad Ali Shodiqin, Muhammadyah Itu NU; Dokumen Fiqih Yang Terlupakan, ( Jakarta Selatan, Naora Books, 2014), 15.
} 
Meskipun dalam kesimpulanya beliau lebih mementingkan persatuan umat, akan tetapi dalam kesimpulan tersebut beliau mengkritik Majlis Tarjih (Muhamadiyah). Dalam hal ini Misbach mempertanyakan kualitas keilmuwan dari ahli tarjih kelompok tersebut. Sebab, menurutnya yang namanya ahli tarjih selain harus mempunyai ilmu yang lengkap, kecerdasan di atas rata-rata, dan amal dan ketaqwaan kepada Allah yang tinggi, mereka juga harus memiliki akhlaq dan ibadah yang bisa mencerahkan dunia. ${ }^{32}$ Menurut beliau hal-hal tersebut sangat jauh dan belum dimiliki oleh Majlis Tarjih. ${ }^{33}$

\section{Konspirasi Melemahkan Agama Islam}

Kemudian juga tentang masalah Keluarga Berencana. Beliau menentang progam pemerintah tersebut. Bentuk penentangan ini penulis temukan dalam kitab tafsir Täj Muslimīn yang menjadi kajian penulis.

Dalam tafsir tersebut Misbach mengatakan bahwa progam Keluarga Berencana (KB) tersebut mengandung muatan politik yang mengatasnamakan kemaslahatan umat. Seperti apa yang telah kita fahami dalam bab sebelumnya yang membahas penafsiran beliau. Di mana politik pembatasan kelahiran ini menurutnya pernah terjadi di masa Raja Firaun Mesir kuno.

Pada saat itu Raja Firaun takut jika Bani Israil - sebagai bangsa pendatang di Mesir melakukan pemberontakan. Kerena melihat jumlah mereka yang lebih banyak dari pada bangsa Qibti - bangsa asli Mesir - yang lebih sedikit.

Akhirnya untuk mengantisipasi hal tersebut Raja Firaun membuat kebijakan politik dengan membuat program kerja paksa untuk Bani Israil dan barang siapa yang tidak mau melakukan harus membayar pajak yang tinggi. Sebab, menurut Raja Firaun dan para penasehat kerajaannya, jika orang itu diperas tenaganya, dibuat susah hatinya, maka mereka akan sulit untuk melahirkan keturunan.

Atas dasar itulah Misbach Mustafa khawatir jika program Keluarga Berencana (KB) hanya dijadikan kendaraan politik orang-orang yang ingin membatasi kelahiran/populasi umat Islam di Indonesia. Apalagi jika melihat sejarah kemunculan program $\mathrm{KB}$ itu sendiri yang muncul dan digagas oleh orang non Muslim.

\footnotetext{
${ }^{32}$ K.H. Misbach Mustofa, al Nur al Mubìn, 103.

33 Ibid., 103.
} 
Jika melihat pada tahun 1406 Hijriyah atau 1985 Masehi di mana pada waktu itu negara Arab (negara Islam) telah menjadi negara yang mulia dan disegani oleh negaranegaralain. Akhirnya menimbulkan kegelisahan bagi negara-negara atau pemimpin negera yang mempunyai sifat seperti Firaun. Dalam artian takut jika eksistensinya kalah dengan negara Arab. Hal itulah yang akhirnya membuat mereka mempropagandakan KB yang merupakan usaha mereka agar kemegahan agama Islam yang dirintis di negara Arab bisa musnah dan bagaimana agar mereka tidak bersatu dan menjadi negara yang besar. Jadi, dalam hal ini beliau berkesimpulan bahwa program Keluarga Berencana (KB) merupakan salah satu usaha dari negara yang mempunyai sifat seperti Firaun, untuk mengurangi eksistensi umat Islam.

\section{E. Penutup}

Dari sini dapat kita ambil suatu kesimpulan di mana masuknya isu sosial disebabkan beberapa hal diantaranya pencatutan namanya dalam isu sosial tersebut padahal Misbach tidak pernah merasa ikut serta di dalamnya. Sehingga beliau ingin mengklarifikasi bahwa beliau tidak terlibat dan beliua malah bersebrangan dengan hal tersebut.

Selain itu sebagai seorang ulama' yang memahami al-Qur'an dan hadis membuat Misbach ingin merespon hal-hal yang dianggapnya tidak sesuai dangan ketentuan syari'at di mana dalam hal ini Misbach ingin menjaga umat dari kesesatan dan perpecahan yang diakibatkan ketidak fahaman mereka terhadap isi kandungan al-Qur'an dan perkara khilafiayah dalam ibadah.

Adapun sikap penolakan Misbach dalam masalah keluarga berencana (KB) menunjukan bahwa beliau adalah orang yang sangat berhati-hati dalam mengambil sikap. Apalagi jika hal tersebut dianggap tidak datang dari dalam Islam, seperti masalah KB. Ia hal tersebut hanyalah sebuah konspirasi untuk melemahkan umat Islam. 


\section{DAFTAR PUSTAKA}

Amien, Shiddiq, Keluarga Berencana; Dalam Pandangan Islam. Bandung: PERSIS, 2001.

Fauzi, M. Nasim, "Masalah Membaca Basmalah di dalam Sholat" http://nasimfauzi.blogspot.co.id/2008/09/pemikiran-bacaan-bismillah.html, (Diakses $22 \mathrm{Mei} 2016)$

Ghaz̄i (al), Muhammad bin Qāsim. Fathu al-Qarīb al-Mujīb. Surabaya: Haromaīn, 2005.

Gusmian, Islah. Khazanah Tafsir Indonesia: Dari Hermeunetika Hingga Ideologi. Yogyakarta: LKIS, 2013.

Gusmian, Islah. “ Dialektika Tafsir Al Qur`an Era Orde Baru”, Desertasi Fakustas Ushuluddin UIN Sunan Kalijaga, Yogyakarta, 2014.

Halim, Abdul. “Epistimologi Tafsir Ibnu `Āsyūr dalam Kitab Tafsir al-Tahrīr wa al-Tanwīr”. Skripsi. Fakultas Ushuluddin UIN Sunan Kalijaga.Yogyakarta, 2011.

Misbach, Muhammad Nafis. Wawancara, Bangilan, 22 April 2016

Mustafa, K. H. Misbach, Tafsir Taj al-Muslimin Min Kalami Robbi al Alamin. Bangilan: Majlis Ta'lif wa al Khatath, 1990.

Mustafa, K.H. Misbach. Al-Nur al-Mubbīn fi àdābi al Muslihīn. Bangilan: Maktabah al Balaq, 1992.

Mustafa, Misbach. BPR NU dalam Tinjauan Al-Qur 'an. Tuban: tnp,1990.

Mustaqim, Abdul, dkk. Studi al Qur'an Kontemporer : Wacana Baru Berbagai Metodelogi Tafsir. Yogyakarta: Tiara Wacana, 2002.

Mustaqim, Abdul. Dinamika Sejarah Tafsir al Qur`an. Yogyakarta: Adab Press, 2014.

Mustaqim, Abdul. Madzhibut Tafsir : Peta Metodelogi Penafsiran al Qur'an Priode Klasik hingga kontemporer. Yogyakarta: Nun Pustaka: 2003.

Shodiqin, Muhammad Ali . Muhammadyah Itu NU; Dokumen Fiqih Yang Terlupakan. Jakarta Selatan, Naora Books, 2014.

Wahid, Abdurrahman. Tabayun Gus Dur., Yogyakarta: Lkis, 2010. 